"Examining factors influencing Indian customers' intentions and adoption of internet banking: Extending TAM with electronic service quality"

\begin{tabular}{|c|c|c|}
\hline AUTHORS & \multicolumn{2}{|l|}{$\begin{array}{l}\text { Amandeep Kaur } \\
\text { Garima Malik }\end{array}$} \\
\hline ARTICLE INFO & \multicolumn{2}{|c|}{$\begin{array}{l}\text { Amandeep Kaur and Garima Malik (2019). Examining factors influencing Indian } \\
\text { customers' intentions and adoption of internet banking: Extending TAM with } \\
\text { electronic service quality. Innovative Marketing, 15(2), } 42-57 \text {. } \\
\text { doi:10.21511/im.15(2).2019.04 }\end{array}$} \\
\hline DOI & \multicolumn{2}{|c|}{ http://dx.doi.org/10.21511/im.15(2).2019.04 } \\
\hline RELEASED ON & \multicolumn{2}{|l|}{ Wednesday, 12 June 2019} \\
\hline RECEIVED ON & \multicolumn{2}{|l|}{ Wednesday, 20 March 2019} \\
\hline ACCEPTED ON & \multicolumn{2}{|l|}{ Friday, 31 May 2019} \\
\hline & \multicolumn{2}{|c|}{$(\infty) E_{\text {EY }}$} \\
\hline LICENSE & \multicolumn{2}{|c|}{$\begin{array}{l}\text { This work is licensed under a Creative Commons Attribution } 4.0 \text { International } \\
\text { License }\end{array}$} \\
\hline JOURNAL & \multicolumn{2}{|l|}{ "Innovative Marketing " } \\
\hline ISSN PRINT & \multicolumn{2}{|l|}{$1814-2427$} \\
\hline ISSN ONLINE & \multicolumn{2}{|l|}{$1816-6326$} \\
\hline PUBLISHER & \multicolumn{2}{|c|}{ LLC “Consulting Publishing Company "Business Perspectives" } \\
\hline FOUNDER & \multicolumn{2}{|c|}{ LLC "Consulting Publishing Company "Business Perspectives" } \\
\hline \multirow{2}{*}{ NUMBER OF REFERENCES } & & ニニ: \\
\hline & NUMBER OF FIGURES & NUMBER OF TABLES \\
\hline 70 & 3 & 4 \\
\hline
\end{tabular}

(C) The author(s) 2023. This publication is an open access article. 


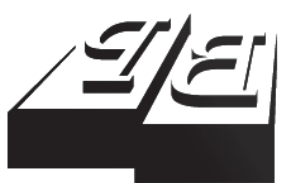

BUSINESS PERSPECTIVES

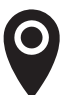

LLC "CPC "Business Perspectives" Hryhorii Skovoroda lane, 10, Sumy, 40022, Ukraine

www.businessperspectives.org

Received on: $20^{\text {th }}$ of March, 2019 Accepted on: $31^{\text {st }}$ of May, 2019

(C) Amandeep Kaur

Garima Malik, 2019

Amandeep Kaur, Research Scholar, Management Studies Faculty, Department of Amity Business School, Amity University, India.

Garima Malik, Associate Professor and Research Scholar, Management Studies Faculty, Department of Amity Business School, Amity University, India.

\section{(ㄷ) (i)}

This is an Open Access article, distributed under the terms of the Creative Commons Attribution 4.0 International license, which permits unrestricted re-use, distribution, and reproduction in any medium, provided the original work is properly cited.

\title{
EXAMINING FACTORS INFLUENCING INDIAN CUSTOMERS' INTENTIONS AND ADOPTION OF INTERNET BANKING: EXTENDING TAM WITH ELECTRONIC SERVICE QUALITY
}

\begin{abstract}
This study conceptualizes and tests an integrative research model based on extended technology acceptance model (TAM) by integrating electronic service quality to strengthen the customer behavioral intention mediated through brand attitude in the context of e-banking in India. This study applies the cognitive, affective, and conative sequence to measure the antecedents and results of electronic service quality. The study has gathered a total of 455 usable responses by self-administered questionnaire through convenience sampling from young employed graduates aged between 16 and 29 years. Structural equation modelling techniques have been applied to the data and the results have provided that dimensions of electronic service quality model (customer service, web design, assurance, preferential treatment, information provision) relate to the electronic service quality. Electronic service quality and perceived usefulness significantly build customer attitude and intention to use internet banking services. However, against the TAM postulation, perceived ease of use does not influence customer's intention to adopt internet banking service.
\end{abstract}

Keywords

\section{JEL Classification M310, O330}

\section{INTRODUCTION}

Information and Computer Technology has become an important tool to achieve competitive advantage. This has become a trend where service companies are pressurized to invest in technology to have a secure future in the technology age (Bauer et al., 2005, p. 162). In this context, banking industry is said to be a demand-driven industry. Since the mid 1990s, the operations in financial market have become challenging enough and banks have felt pressure to use alternate delivery channels having a significant shift from branch banking towards self service medium of internet banking. The success of this radical innovation, internet banking, cannot be determined by the banks only or support provided by government but when customers accept it and use it (Al-Somali et al., 2008). Internet banking refers to transacting all bank-related tasks anytime from any part of the world via a secure web channel operated by the bank (Bashir \& Madhavaiah, 2014, p. 159).

The internet has seen a tremendous growth over the few years, but the internet tapping in developing countries is low in numbers as compared to developed countries (Mundra, 2015). This indicates the inherent opportunities in the banking sector. Moreover, the in- 
creased numbers of Automated Teller Machines (ATMs), Real Time Gross Settlement (RTGS)/National Electronic Funds Transfer (NEFT) transactions, number of internet banking users all over in India, the nation's banking industry is definitely considering the need of masses (Clonia \& Asht, 2016). Customer preferences for internet banking are increasing because of time and cost convenience and the factors responsible for low entry barriers may be returns that are promising and manageable uncertainties (Jayawardhena \& Foley, 2000, p. 27). Also, new technologies like mobile banking, electronic wallets linked to banks, entry barriers have been lowered (Aboelmaged \& Gebba, 2013, p. 40). Therefore, banks need to provide customers with a service having high quality, which is now a key ingredient in the success of banks.

Now, the adoption of internet banking by customers depends on the motivation to accept technology, since it involves changing behavioral patterns. And this behavior is again based on customer experience with respect to content delivery on the channel (Laforet \& Li, 2005, p. 372). Thus, the researchers have been investigating the extent to which customer use as an important indicator of experience in order to reduce uncertainty and risk of adopting new technology (Eriksson et al., 2005, p. 209). This is the serious concern that prevails in the use of internet banking (Suh \& Han, 2002, p. 258). And of all the segments who are the users of IB the potential segment is young consumers (Bashir \& Madhavaiah, 2014, p. 156). Demography is a popular way of segmenting customers, particularly the age of customers. These customers adopt internet banking services quite faster than other customer segments, because consuming such services easily fits in their lifestyles. Young customers are educated, talented and above all tech savvy. There is a definite need to measure the factors that contribute to the young customers' intention to adopt internet banking (IB), so that banks will be able to design their operational strategies for young customers to increase internet banking usage in the future.

Many previous studies in the past by the researchers provided developed models to study the customer's behavior in internet banking environment. These included, but not restricted to, Theory of Reasonable Action (Fishbein \& Ajzen, 1975), Theory of Planned Behavor (Ajzen, 1985), Decomposed Theory of Planned Behavior (Taylor \& Todd, 1995), Technology Acceptance Model (Davis et al., 1989) Technology Acceptance Model 2 (Venkatesh \& Davis, 2000), Unified Theory of Acceptance and Use of Technology (Venkatesh et al., 2003). One such model which is widely accepted had recurrently proved that customer's acceptance of any new technology or information system depends on his/her intention to use that system and further argued that intention is a consequence of attitude and belief, namely perceived ease of use and perceived usefulness. Technology acceptance model (TAM) is tailored for modelling users' acceptance of information systems or technologies. The belief of the user towards a system may be influenced by other factors referred to as external variables in TAM. Thus, it has been further extended by many other researchers. There have been numerous dimensions added to the model over the period of time, but the customer adoption behavior has also changed over the time. However, the success of electronic related transactions does not merely depend on website attractiveness, but its service quality, thus electronic service quality is becoming an important contributor in the success of internet banking (Ariff et al., 2012, p. 856). The studies have been reviewed where the young customers preferred channels have been studied and identified how technologically oriented consumers are ignorant towards internet banking service and their choice of bank. From a review of the extant literature, the observation is that the dimensions of electronic service quality have been evaluated in the internet banking context, while relatively little literature has investigated adding the electronic service quality as a dimension in the technology acceptance model along with perceived ease of use and perceived usefulness and scarce literature measured its impact on the behavioral intention towards adoption of mediated through customer's attitude.

This paper presents a discussion of the developments in the technology acceptance model by integrating electronic service quality as its factor and analyzes the customer's perception about its effect on their likely attitude and intention. 
In this following paper, first, we synthesize previous studies that highlight potential factors that determine the adoption of internet banking. Based on these gaps in studies, we present the objectives of our study. Second, the utilized research methodology is presented. Third, we draw the empirical findings based on theoretical framework depicting the factors perceived by young customers for adoption of internet banking. Fourth, we discuss the main findings and outline some implications for managers and, fifth, we suggest future research and offer concluding remarks.

For the purposes of this paper, internet banking includes ATM (Automatic Teller Machines) point of sale transactions, transfers within the same banks, third party accounts and other banks as well.

\section{LITERATURE REVIEW}

\subsection{Technology acceptance model (TAM)}

TAM has been a robust model that was developed by Davis $(1989$, p. 325$)$ to predict the individual acceptance of information systems. Later on, this model has been applied in different conditions to investigate customer acceptance in all types of information technology with a rich empirical support. This model can predict the contributing factors for acceptance of a system and facilitate the experience within the system and it is based on the notion that the acceptance is driven by the intentions of using the system. Those intentions are again a consequence of the attitude of an individual and further this attitude is also influenced by perceived ease of use and perceived usefulness.

Researchers have also extended TAM by adding factors to it, such as Venkatesh and Davis (2000) developed TAM 2 by adding social influences and cognitive instrumental processes. Further, Venkatesh et al. (2003) integrated the elements of eight prominent theories and models, includ- ing Theory of Reasoned Action (Fishbein \& Ajzen, 1975), Technology Adoption Model (Davis, 1989), Motivational Model (Davis et al., 1992), Theory of Planned Behavior (Ajzen, 2002), combined TAMTPB (Taylor \& Todd, 1995), Model of Personnel Computer Utilization (Thompson et al., 1991), Innovation Diffusion Theory (Roger, 2003), Social Cognitive Theory (Bandura, 1986) and developed Unified theory of Acceptance and Use of Technology containing four determinants of intention and usage, including performance expectancy, effort expectancy, social influence and facilitating conditions.

In all the theories mentioned above, two belief constructs can be easily identified, namely perceived ease of use and perceived usefulness. Therefore, we can say that TAM is the most influential theory in IS field and the structure and assumptions of this model remain the same as in all other theories.

This model has been tested by several studies (Venkatesh \& Davis, 2000, p. 197; Bruner \& Kumar, 2005, p. 556; Foxalle \& Pallister, 2007; Sebetci, 2015, p. 129; Lai, 2017, p. 35). The origi-

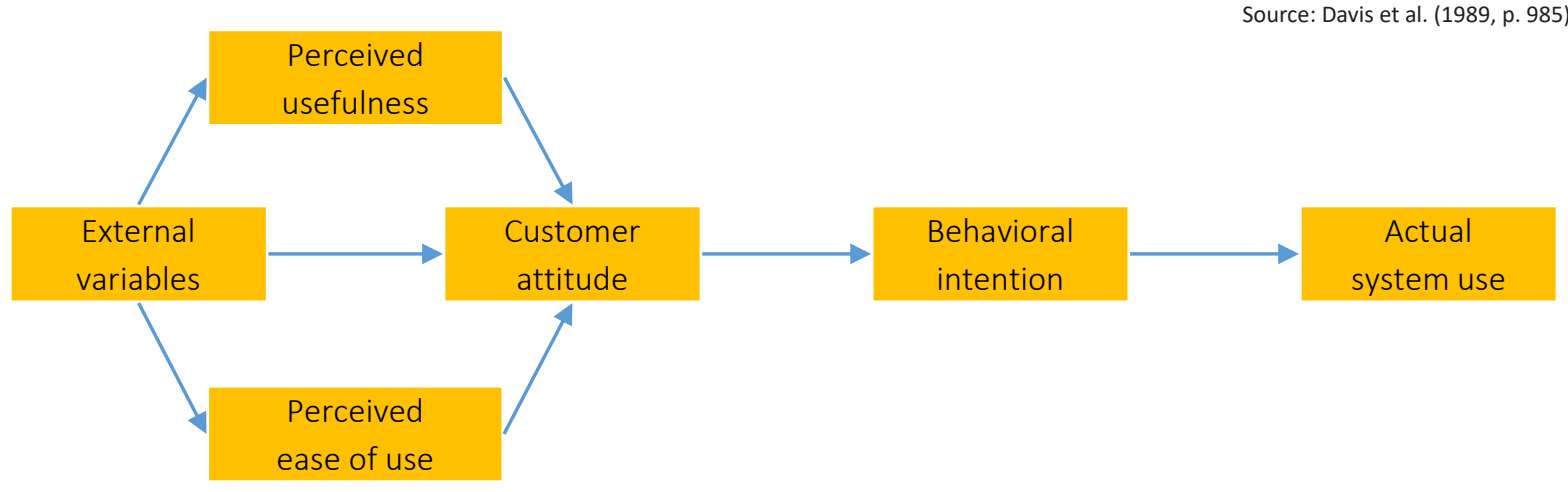

Figure 1. The technology acceptance model 
nal TAM was supported by many researchers, but these days the internet banking environment is changing and different from the conventional IT, thus, for studying the acceptance of internet banking, the original TAM is inadequate (Safeena et al., 2013, p. 146). It is because of the TAM inherited purpose of defining this model in the context of technology aspects only, and other factors of social and psychological nature are ignored in this model. On the other hand, many researchers who have used TAM did not get much success and other factors gained significant results.

\subsection{E-service quality concept}

There have been numerous studies with their research on the definition and measurement of service quality concept. Parsuraman et al. (1985, p. 43) defined service quality as the "gap between customer's service expectation and their perception about service they have experienced". According to Bitner and Hubbert (1994, p. 83), "service quality is consumers' overall impression of the relative inferiority/superiority of the organization and its services". Parasuraman $(1988$, p. 12) brought out the concept of service quality in traditional sense where it is all about the customer's interactions with the service provider face to face, hence, non internet bases, however, the advent of information technology gives due importance to concept of e-service. Electronic service provides an interactive format that is information-centred and refers to online (internet) based customer service that is facilitated by customers and performed with the support of technologies made available by service providers that intend to enhance the customer-organization relationship (de Ruyter et al., 2001, p. 192). This service is provided through web or an interactive platform like internet banking where bank's customers perform their banking activities through bank's website. Parasuraman et al. (2005, p. 223) defined e-service quality as "the extent to which a website facilitates efficient and effective shopping, purchasing, and delivery". Huge competition in banking industry and having similar products lead to a challenge of differentiation where delivering superior quality of internet service in banking operations is a major opportunity (Ranganathan \& Ganpathy, 2002, p. 461). And by referring to quality of service in internet banking results in attracting and retaining customers (Liao
\& Cheung, 2002, p. 289). When quality of service has been studied and measured in e-commerce environment before, different scales have been developed and tested to analyze the electronic service quality in e-commerce environment. Scales such as E-SERVQUAL, WebQual, SITEQUAL and eTailQ have been validated in different service contexts.

The scale developed to measure the service quality as difference between customer's expectation and their perception was given by Parasuraman et al. (1988, p. 12), originally along five dimensions applicable only in traditional environment, namely tangibles, reliability, responsiveness, assurance and empathy. Further, to test the service quality in online environment, related scale was developed by Sohail and Shaikh $(2008$, p. 66) and named as WebQual, which consists of 12 dimensions for measuring website quality. The scale provided makes relevance to give insights to web designers, but did not provide much information for service quality. Further, a four dimension scale, SITEQUAL, developed by Yoo and Donthu (2001, p. 10) measured perceived quality in e-commerce environment, particularly online shopping site, this scale is helpful for extended studies in this field only. Next, the original SERVQUAL scale was transformed by Parasuraman et al. $(2005$, p. 220) in an online context for customers who shop on internet named as E-S-QUAL having four dimensions such as efficiency, fulfilment, privacy and system availability. Many extensions of the original model also produced significant results, such as a study conducted by Firdous and Farooqi (2017) who extended E-S-QUAL and E-REC-SQUAL model of Zeithmal et al. to the banking sector and customers gave higher weight to website performance. Recently, Taherdoost (2018, p. 188) contributed in this field by developing e-service technology acceptance model and identified factors that are important to measure the acceptance of e-service technology, satisfaction, quality and security with their antecedents.

Key service quality dimensions identified majorly as per studies that developed original scales and validated in different contexts are responsiveness, assurance, fulfilment, reliability, efficiency, privacy/security, website design (Ho \& Lin, 2010, p. 19; Kadir et al., 2011, p. 1; Gupta \& Bansal, 2012, p. 11; Ariff et al., 2012, p. 857; Taherdoost, 2018, p. 190). 


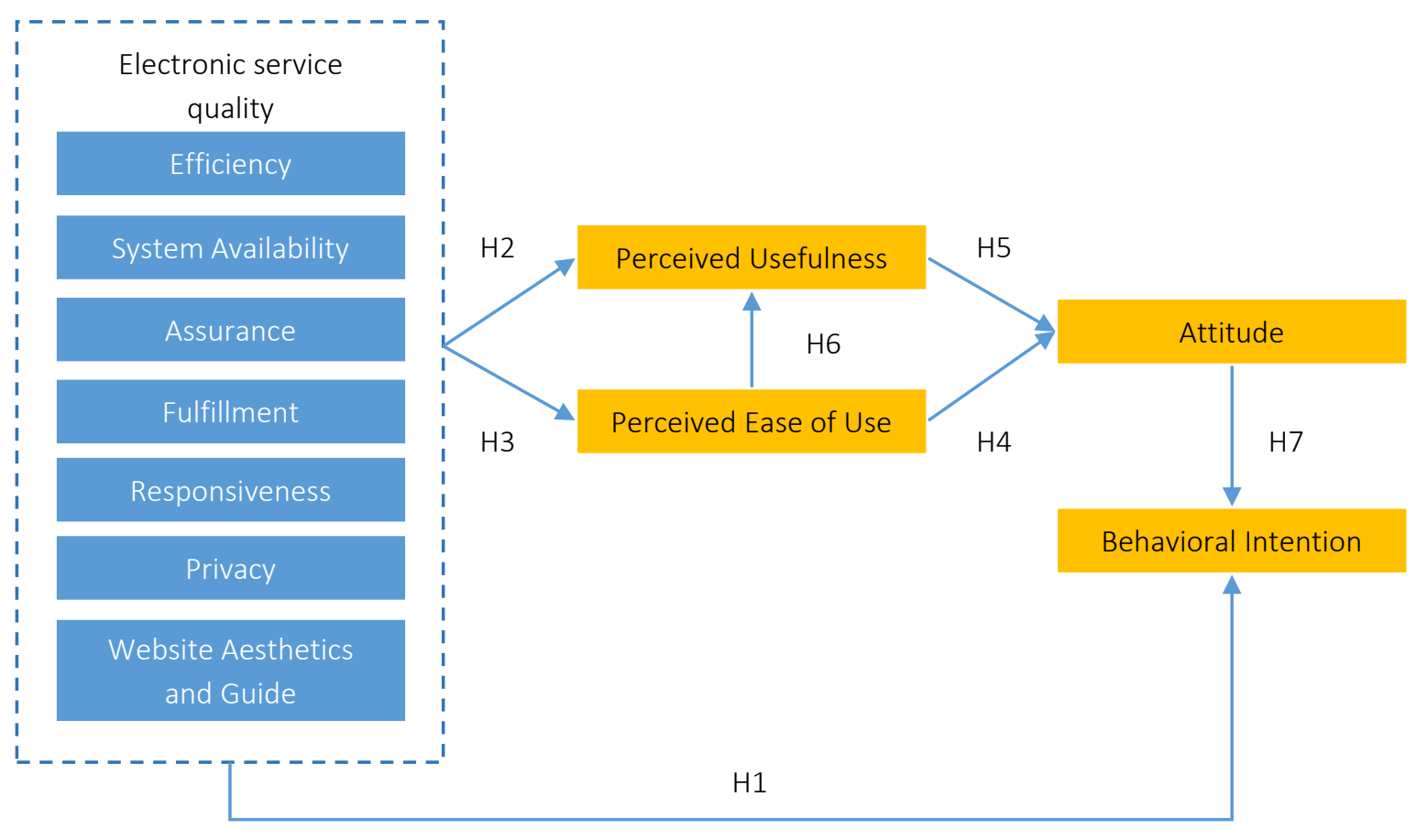

Figure 2. Proposed research model

Although many studies have highlighted the importance of electronic service quality in order to satisfy customers, very few studies have been carried out towards the largest segments of customers, that is of young people. Tardivo et al. (2014, p. 205) studied the young customer's perception towards e-service quality in mobile banking and reported that young customers express the satisfaction with security of transaction, reliability of the operations and compatibility with respect to the websites providing easy visualization, however, dissatisfaction is reported in respect of lack of constant information about the innovations. Another study in respect of online shopping provided understanding that majority of young adults are heavy internet users and they need fast, uncluttered information with interactive website technologies to ease the flow with other factors such as reliability, privacy and security of transactions as important dimensions of e-service quality. Young customers highlighted that the most important dimension they consider is customer service meaning easy communications (both offline and online channel) with staff members when required (Mohd-Any et al., 2016, p. 106).

In order to provide a solid theoretical base to understand the influence of customers' perceptions about electronic service quality on their intention to use internet banking, this paper drew upon in- tegrating dimensions of electronic service quality with technology acceptance model. Technology acceptance model have been extended with many other variables earlier for improvement of its explanatory power (Venkatesh et al., 2003, p. 450). However, with the development of technology, it is expected that the young segment will increase their use of alternative banking services that offer good online quality service, therefore, banks are required to build their systems, which provide secure service that takes care of privacy of customers data, be efficient and responsive to customers queries and have easy interface of the website (George \& Kumar, 2014, p. 79). Hence, the integration of electronic service quality in the technology acceptance model will be explored from the perspective of millennial and changing economy.

\subsection{Research model and hypotheses}

Having studied many contributing theories and variables in the literature, this study aims to integrate the electronic service quality in internet banking context combined with technology acceptance model to study the adoption intention of the customers. The developed research model is illustrated in Figure 2. The model constitutes five variables: Electronic Service Quality (ESQ) with seven sub-dimensions, Perceived Ease of Use 
(PEOU), Perceived Usefulness (PU), Customer Attitude (AT) and Behavioral Intention (BI). In the first part of proposed model, the electronic service quality is expressed by Efficiency, System Availability, Assurance, Fulfilment, Privacy, Responsiveness, Website Aesthetic and Guide and the second part is about linking the dimensions of ESQ with the technology acceptance model, Perceived Usefulness and Perceived Ease of Use and subsequently leading to Attitude and Behavioral Intention.

Seven hypotheses are proposed in the research model and these hypotheses are empirically tested based on survey results which shall be discussed in subsequent sub-sections. Each construct of the research model is explained below in detail along with related hypotheses and its relation with other constructs.

\subsection{Electronic service quality and behavioral intention}

The researchers have brought out the scales that measured the customer perceptions about electronic service quality in internet banking context. Based on these researches, seven factors have been identified, namely Efficiency (Sohail \& Shaikh, 2007, p. 66; Ho \& Lin, 2010, p. 14; Ariff et al., 2012, p. 856; George \& Kumar, 2014, p. 79), System Availability (Sohail \& Shaikh, 2007; Khan et al., 2009; Ariff et al., 2012; George \& Kumar, 2014), Assurance (Sohail \& Shaikh, 2007; Ho \& Lin, 2010; Nupur, 2010; Kadir et al., 2011; Ariff et al., 2012; George \& Kumar, 2014), Fulfillment (Shaikh, 2007; Ho \& Lin, 2009; Nupur, 2010; Kadir et al., 201; Ariff et al., 2012; George \& Kumar, 2014), Responsiveness (Sohail \& Shaikh, 2007; Ho \& Lin, 2010; Ariff et al., 2012; George \& Kumar, 2014), Privacy (Sohail \& Shaikh, 2007; Ho \& Lin, 2009; Ariff et al., 2012; George \& Kumar, 2014) and Website Aesthetic and Guide (Ariff et al., 2012).

Efficiency provides customer to input on the site with minimum information, easy to use and structured website (George \& Kumar, 2014, p. 82), System Availability ensures the availability and functionality of site that drive the completion of all the transactions required by the customer, Assurance deals with the customer feeling confident in transacting online on bank's website and fulfilment is to what extent the transaction needs and other tasks are fulfilled (Ariff et al., 2012, p. 857), Responsiveness should measure the level of assistance provided by banks representatives and customers access to it for handling internet banking problems and Privacy should examine the security and confidentiality of customers' data (Sohail \& Shaikh, 2007, p. 67), a dimension added by Ariff et al. (2012, p. 856), Website Aesthetics and Guide, will offer aesthetic values and bank's website to look more appealing and provide enough guidance, information to the customers of bank's internet service. This research extends to measure the adoption intention of internet banking by using the abovementioned dimensions of e-service quality into technology acceptance model. Boakye et al. $(2014$, p. 18) provided quality-technology acceptance model that integrated original TAM with quality framework from the perspective of technology operations of employees. The dimensions studied to measure the consumer intention to continue using technology have an attribute of reliability, which is an important contributing factor. Further, previous studies have shown that few of the dimensions of service quality - efficiency, fulfilment, privacy and availability - have positively influenced the intention to adopt internet banking (NezamZade, 2009; Khanifar et al., 2012, p. 1849; Hien, 2014, p. 18). Few more studies provided a model that showed an effect of service quality of online banking on customers' acceptance and satisfaction. The customer expects that banks should provide 24/7 service with visual layout and up-todate information with strengthening of security measures and concentrating on technical formalities (Singh, 2019, p. 324; Amin, 2016, p. 293). These are yet other studies to understand the customer's attitude and their relationship with internet banking.

Hence, we propose our first hypothesis:

H1: E-service quality positively influences behavioral intention.

\subsection{Electronic service quality, $\mathrm{PU}$, and PEOU}

Building upon TAM and to tailor the model to the specifications of internet banking adoption, electronic service quality dimensions in internet 
Table 1. Profile of respondents

\begin{tabular}{|c|c|c|c|c|}
\hline Measure & Value & Frequency & Percentage & Cumulative, $\%$ \\
\hline \multirow{2}{*}{ Gender } & Male & 326 & 71.6 & 71.6 \\
\hline & Female & 129 & 28.4 & 100 \\
\hline \multirow{5}{*}{ Education } & School and Diploma & 20 & 4.4 & 4.4 \\
\hline & Bachelor's Degree & 126 & 27.7 & 32.1 \\
\hline & Master's Degree & 273 & 60 & 92.1 \\
\hline & Professional Degree & 26 & 5.7 & 97.8 \\
\hline & Others & 10 & 2.2 & 100 \\
\hline \multirow{4}{*}{ Occupation } & Private Employee & 300 & 65.9 & 65.9 \\
\hline & Govt. Employee & 91 & 20 & 85.9 \\
\hline & Business & 49 & 10.7 & 96.6 \\
\hline & Others & 15 & 3.4 & 100 \\
\hline \multirow{4}{*}{ Internet usage experience } & Less than 2 years & 22 & 4.8 & 4.8 \\
\hline & 2 to 4 years & 72 & 15.8 & 20.6 \\
\hline & 4 to 6 years & 124 & 27.2 & 47.8 \\
\hline & More than 6 years & 237 & 52.2 & 100 \\
\hline
\end{tabular}

banking context were identified and incorporated into the existing TAM. There is accumulated evidence supporting the relationship between perceived usefulness, perceived ease of use and intention, but service quality as predictor of perceived ease of use and perceived usefulness is much less studied. However, a study by Shin $(2009$, p. 20) highlighted that perceived usefulness and perceived ease of use mediate the relationship between electronic service quality and intention. Therefore, we hypothesize that:

\section{H2: E-service quality positively influences perceived usefulness.}

\section{H3: E-service quality positively influences perceived ease of use.}

\subsection{PU, PEOU and brand attitude}

There has been plethora of researches that have considered the impact of PEOU, PU on customer's attitude towards brand under technology acceptance studies (Alsajjan \& Dennis, 2010, p. 960; Shen \& Chiou, 2009, p. 400). Measuring this impact facilitates interpretation of the cognitive processes for better results that provide understanding about the beliefs, attitudes and actual behavior that customers tend to respond (Lai \& Li, 2005, p. 380 ) and, hence, the relationship between the perceived ease of use/perceived usefulness and brand attitude is necessarily considered. Hosein (2009, p. 60) mentioned that if the technology is easier to use and perceived to be more useful to carry out activities, the more positive is the customer's attitude towards leveraging that technology, thus, its usage increases. In a theoretical base for adoption of Internet banking, the impact of PEOU on customer's attitude is widely investigated and results suggested that this relationship is a critical factor contributing to the internet banking adoption (Yiu et al., 2007, p. 342). Additionally, plethora of researches on technology acceptance have given a significant and direct impact of PU on consumer's attitude to use and adopt internet banking service as measured by Alsajjan and Dennis (2010, p. 960), Chau and Ngai $(2010$, p. 50) and originally provided by Davis et al. $(1989$, p. 324). Therefore, the following hypotheses have been formulated:

H5: Perceived usefulness positively influences brand attitude.

H6: Perceived ease of use positively influences perceived usefulness.

\subsection{Brand attitude and behavioral intention}

Previous analytical studies having background of innovative technology diffusion have expanded the use of TAM to include user's attitude as defined by another related study, Theory of Reasoned Action (Davis et al., 1989, p. 337; Jayawardhena \& Foley, 2000, pp. 19-31; Karjaluoto et al., 2002, p. 268). TAM suggested that attitude is formed from the salient beliefs which a customer has about the consequences of a given behavior and his or her 
evaluation of those consequences. In the internet banking context, customers' attitude is disparate in terms of perceptions regarding service performance, fee involved, delivery terms, service offered, risk involved, and reputation of bank, security, relative advantage and convenience. Understanding the determinants of customer attitude, researchers have argued that the customer attitude towards a brand has a strong, direct and positive effect on behavioral intention to adopt internet banking (Eriksson et al., 2005, p. 212; Jung $\&$ Seock, 2016, p. 18). Hence, the following hypothesis is expected:

H7: Brand attitude positively relates to behavioral intention.

\section{RESEARCH METHODOLOGY}

In the era, a new set of young customers are evolving, especially from urban areas who are embracing internet banking for various operations. The aim was to explore and identify the factors contributing to the attitude and intention and recognize the relationship among various factors that are contributing to the attitude and intention to adopt internet banking service.

\subsection{Sampling and data collection}

The data for the study were collected though a structured questionnaire distributed among the young employed graduates aged between 16 and 29 years in Delhi. Since the study is based on young customer segment, which is a potential segment for internet banking, this sample is considered to be the ideal. Also, this segment is tech savvy, risk taking and enthusiast, thus, they have more access to the internet as compared to other segments. Convenience sampling method was adopted to make sure respondents are in the age group of 16-29 years, well-educated and computer users. The usable responses recorded were 455. In the first section of the questionnaire, questions included are about respondent's demographic profile, current use or non-use of internet banking and frequency of using internet. The second section aimed at measuring the main constructs used in the study. The questionnaire was adaptive from previous researches with minor changes in inter- net banking context for young generation. The descriptive statistics of demographic particulars of respondents are presented in Table 1.

Out of 455 respondents, 28.4 percent are female and 71.6 percent are male. All the respondents fall under the age group of 16-29 years, as the data were collected only from the respondents aged above 16 years and with age less than 29 years. Majority of respondents (60 percent) were Master's Degree holders. Most of the respondents are employed in private sector (65.9 percent). More than 50 percent of respondents have been using internet for more than six years.

\subsection{Measurement instrument}

A number of key questions stem from literature review, and content validity of the scale was ensured by using the items extracted from previously validated technology acceptance studies and revised properly for the internet banking adoption. The participants indicated their agreement using a five-point Likert scales ranging from Strongly Disagree (1) to Strongly Agree (2). A pre-test was undertaken that comprises 67 respondents who have experience with internet banking. The complete data collected from 455 respondents are analyzed and discussed in the next section. The survey included the following dimensions of electronic service quality: Efficiency, System Availability, Fulfillment, Assurance, Responsiveness, Privacy, Website Aesthetic and Guide as extracted from Ariff et al. (2012, p. 857), George and Kumar (2014, p. 81). Customer Attitude (containing five items) from Maduku (2013, p. 92), Perceived Ease of Use (containing four items), Perceived Usefulness (containing five items) and Behavioral Intention (containing four items) are adopted from Bashir and Madhavaiah (2015, p. 159). Slight modifications in scale items are done to make it understandable by consumers using internet banking.

\section{ANALYSIS AND RESULTS}

In analyzing the questionnaire, means, frequencies and reliabilities were first calculated using SPSS software and as mentioned, content validity was established by reviewing existing literature. Authors have tested the proposed model by ap- 
plying confirmatory factor analysis first to check the fitness of the model and further to measure the direct and indirect relationships among selected variables, structural equation modelling using AMOS 18 was applied. Before testing and creating the full measurement model, the zero order, first order and second order CFA's were carried out that specified the measurement model and further tested the reliability of each construct, validated it and confirmed the measurement model. Tables 2 and 3 provide reliability and correlation statistics among selected variables. Table 2 shows the Average Variance Extracted (AVE), composite reliability and the Cronbach's alpha for all the constructs. Table 2 presents the Cronbach's alpha coefficients for each construct to be more than the common threshold value $(0.70)$ recommended by Agarwal and Karahanna (2000, p. 682), which rep- resents that constructs measured to prove good reliability.

Table 2 presents values of AVE to be above threshold of 0.5 as an evidence of attaining convergent validity (Molina et al., 2007). This explains the appropriateness of the measurement instrument.

Further discriminant validity was measured by calculating the square root of AVE, which needs to be higher than correlation coefficient between any other pair of construct for the particular construct to show accepted discriminant validity (Fornell \& Larcker, 1981, p. 385). Next, Table 3 presents that the selected constructs attained satisfactory discriminant validity. Also, all variables were taken into factor analysis to confirm the common method bias; all items were loaded onto one single factor.

Table 2. Confirmatory factor analysis statistics

\begin{tabular}{|c|c|c|c|c|c|}
\hline Construct & $\begin{array}{c}\text { Measured } \\
\text { variable }\end{array}$ & $\begin{array}{c}\text { Standardized } \\
\text { loading }\end{array}$ & $\begin{array}{l}\text { Composite } \\
\text { reliability }\end{array}$ & $\begin{array}{c}\text { Cronbach's } \\
\text { alpha }\end{array}$ & $\begin{array}{c}\text { Average Variance } \\
\text { Extracted (AVE) }\end{array}$ \\
\hline \multirow{21}{*}{ Electronic service quality } & ESQ1 & 0.919 & \multirow{21}{*}{0.888} & \multirow{21}{*}{0.836} & \multirow{21}{*}{0.622} \\
\hline & ESQ2 & 0.845 & & & \\
\hline & ESQ3 & 0.926 & & & \\
\hline & ESQ4 & 0.933 & & & \\
\hline & ESQ5 & 0.743 & & & \\
\hline & ESQ6 & 0.952 & & & \\
\hline & ESQ7 & 0.869 & & & \\
\hline & ESQ8 & 0.963 & & & \\
\hline & ESQ9 & 0.966 & & & \\
\hline & ESQ10 & 0.742 & & & \\
\hline & ESQ11 & 0.893 & & & \\
\hline & ESQ12 & 0.825 & & & \\
\hline & ESQ13 & 0.936 & & & \\
\hline & ESQ14 & 0.712 & & & \\
\hline & ESQ15 & 0.933 & & & \\
\hline & ESQ16 & 0.904 & & & \\
\hline & ESQ17 & 0.863 & & & \\
\hline & ESQ18 & 0.899 & & & \\
\hline & ESQ19 & 0.901 & & & \\
\hline & ESQ20 & 0.912 & & & \\
\hline & ESQ21 & 0.936 & & & \\
\hline \multirow{4}{*}{ Perceived Ease of Use } & PEOU1 & 0.926 & \multirow{4}{*}{0.798} & \multirow{4}{*}{0.895} & \multirow{4}{*}{0.599} \\
\hline & PEOU2 & 0.935 & & & \\
\hline & PEOU3 & 0.914 & & & \\
\hline & PEOU4 & 0.829 & & & \\
\hline \multirow{5}{*}{ Perceived Usefulness } & PU1 & 0.785 & \multirow{5}{*}{0.895} & \multirow{5}{*}{0.963} & \multirow{5}{*}{0.632} \\
\hline & $P \cup 2$ & 0.712 & & & \\
\hline & PU3 & 0.963 & & & \\
\hline & PU4 & 0.846 & & & \\
\hline & PU5 & 0.811 & & & \\
\hline \multirow{5}{*}{ Attitude } & AT1 & 0.798 & \multirow{5}{*}{0.961} & \multirow{5}{*}{0.976} & \multirow{5}{*}{0.589} \\
\hline & AT2 & 0.736 & & & \\
\hline & AT3 & 0.823 & & & \\
\hline & AT4 & 0.901 & & & \\
\hline & AT5 & 0.888 & & & \\
\hline \multirow{4}{*}{ Behavioral Intention } & $\mathrm{B} \mid 1$ & 0.623 & \multirow{4}{*}{0.771} & \multirow{4}{*}{0.870} & \multirow{4}{*}{0.543} \\
\hline & $\mathrm{B} 12$ & 0.702 & & & \\
\hline & $\mathrm{B} 13$ & 0.975 & & & \\
\hline & $\mathrm{B} 14$ & 0.898 & & & \\
\hline
\end{tabular}


Table 3. Assessment of discriminant validity

\begin{tabular}{c|c|c|c|c|c}
\hline \multirow{2}{*}{ Construct } & \multicolumn{5}{|c}{ Correlation matrix } \\
\cline { 2 - 6 } & ESQ & PEOU & PU & AT & BI \\
\hline ESQ & 0.622 & - & - & - \\
PEOU & 0.753 & 0.825 & - & - \\
PU & 0.655 & 0.398 & 0.832 & - \\
AT & 0.562 & 0.742 & 0.584 & 0.871 & - \\
BI & 0.519 & 0.23 & 0.523 & 0.5 \\
\end{tabular}

Considering sample sensitivity and model complexity, Chi-square/df (CMIN/DF), GFI, TLI, CFI and RMSEA are considered to be used in this study. It is checked that quite all goodness of fit statistics is in the acceptable range of a well-fit model with ratio of $\mathrm{X} 2 / \mathrm{df}=3.122, p>0.05$ along with other results for GFI, CFI, TLI, RMSEA whichare $.922, .913, .905, .050$, respectively. All fit indices were acceptable. Therefore, integration of electronic service quality in technology acceptance model would provide additional information to predict behavioral intention of using internet banking. The hypotheses were estimated by structural model. The results and complete standardized path coefficients of the research model are listed in Table 4.
Table 4. Results of hypotheses testing

\begin{tabular}{|c|c|}
\hline Hypothesis & Path coefficient \\
\hline $\mathrm{H} 1(\mathrm{ESQ} \rightarrow \mathrm{BI})$ & $0.725 * * *$ \\
\hline $\mathrm{H} 2(\mathrm{ESQ} \rightarrow \mathrm{PU})$ & $0.566^{* *}$ \\
\hline $\mathrm{H} 3(\mathrm{ESQ} \rightarrow \mathrm{PEOU})$ & $0.625^{* *}$ \\
\hline $\mathrm{H} 4(\mathrm{PEOU} \rightarrow \mathrm{AT})$ & $0.356^{* *}$ \\
\hline $\mathrm{H} 5(\mathrm{PU} \rightarrow \mathrm{AT})$ & $0.636 * * *$ \\
\hline $\mathrm{H} 6(\mathrm{PEOU} \rightarrow \mathrm{PU})$ & 0.052 \\
\hline $\mathrm{H} 7(\mathrm{AT} \rightarrow \mathrm{BI})$ & $0.632 * * *$ \\
\hline
\end{tabular}

Note: $* * *$ Represents significance at 0.01 level, ** represents significance at 0.05 level.

From Table 4, it is clear that electronic service quality (ESQ) to Behavioral Intention (BI), Perceived Usefulness (PU) to Attitude (AT) and Attitude (AT) to Behavioral Intention (BI), all

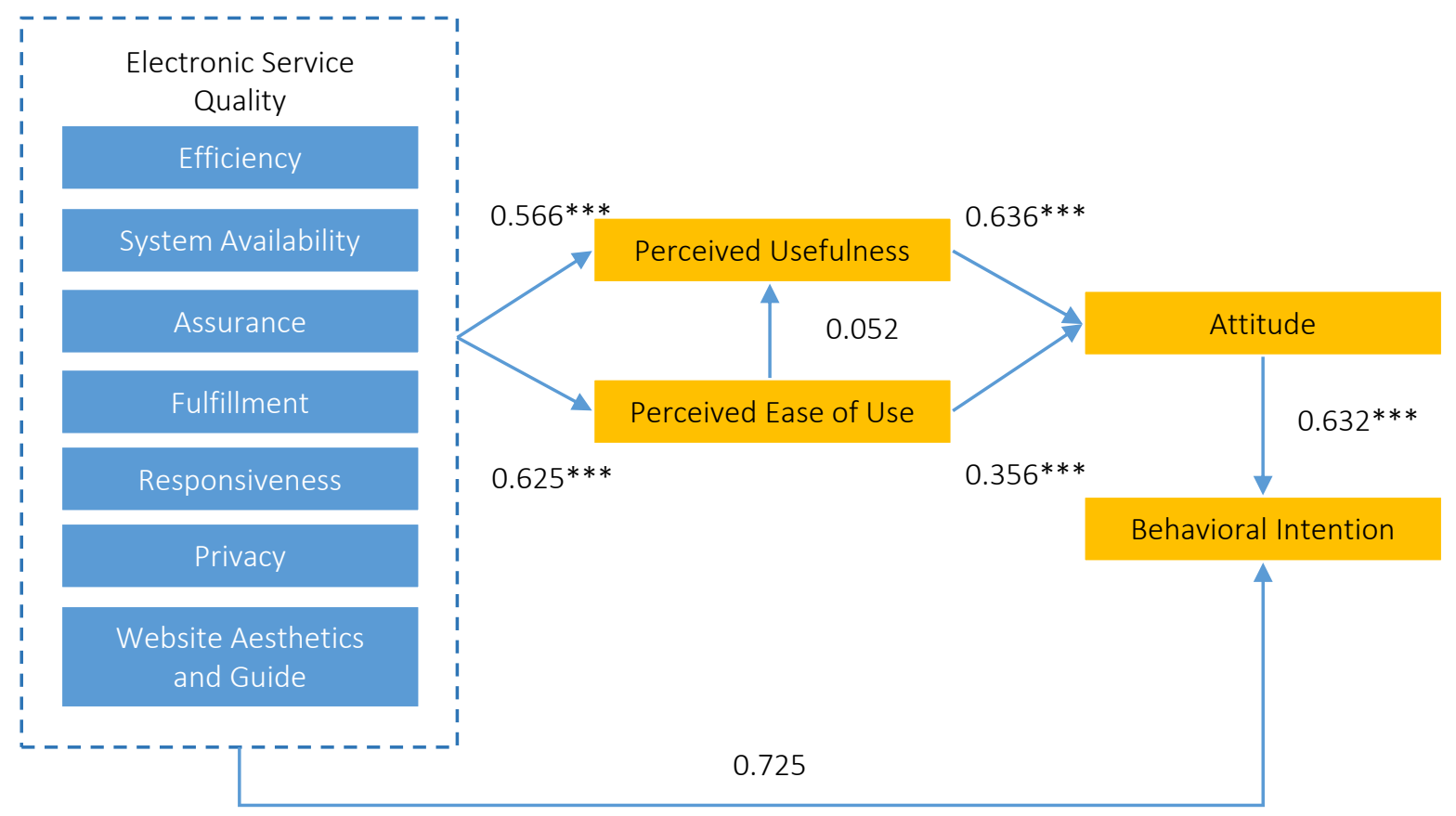

Note: $* * *$ Represents significance at 0.01 level, ${ }^{* *}$ Represents significance at 0.05 level.

Figure 3. Results of structural model testing 
three hypotheses are significant at 0.01 level $\left({ }^{* *}\right)$. Electronic service quality (ESQ) to Perceived Usefulness (PU), electronic service quality (ESQ) to Perceived Ease of Use (PEOU), Perceived Ease of Use (PEOU) to attitude (AT), all three hypotheses are significant at 0.05 level. Perceived Ease of Use (PEOU) to Perceived Usefulness (PU) are not significant having $p$-value of 0.052 .

For the main body of the research model, all the research hypotheses proposed were supported, except one hypothesis (H6: perceived ease of use $\rightarrow$ perceived usefulness). The results of this study prove that customer's view in respect of perceived ease of use and perceived usefulness determines the attitude and behavioral intention. Further, the results also indicate that electronic service quality, which is an antecedent of behavioral intention, positively affects the customer beliefs and influences customer's intention to adopt internet banking directly and through perceived ease of use and perceived usefulness. The result is in line with the previous studies (Khanifar et al., 2012, p. 1849). Also perceived ease of use does not influence perceived usefulness for the young generation to adopt internet banking. The results also contributes to our understanding that customer attitude is an important mediating link between electronic service quality, perceived ease of use, perceived usefulness and behavioural intention. This means that electronic service quality integrated with TAM variables is significant in influencing young customers' attitude and behavioral intention towards internet banking adoption.

\section{DISCUSSION AND THEORETICAL IMPLICATIONS}

Present study provides a theoretical framework that considers how electronic service quality, perceived usefulness, perceived ease of use affect customer attitude and behavioral intention towards internet banking adoption. The structural equation modelling results confirm fitness of the research model. That is how integrated model of technology adoption model with e-service quality is able to explain the factors that influence young generations' customer intention to adopt internet banking. To the best knowledge, this is a unique empirical study that measures the importance of electronic service quality of banks providing internet banking service for young customers who are tech savvy and efficient in online dealings to evaluate if it affects their belief toward its usefulness and ease of use and, thus, influences their intention. Electronic service quality emerged as direct factor to influence intention to adopt internet banking. The findings showed that the seven characteristics (Efficiency, System Availability, Assurance, Fulfilment, Responsiveness, Privacy, Website Aesthetic and Guide) as a part of e-service quality dimension have a significant effect on behavioral intention in Indian banking sector. The result is supported by previous research (Hammoud et al., 2018, p. 7; NezamZade, 2009; Khanifar, 2012, p. 1849). This implies that using a bank's electronic services offers clients a chance to be cost effective by saving not just money but time, efficient, steady delivery of the service, staff responsiveness and timely communication, easy navigability and website attractiveness and importantly privacy of transactions.

Second, e-service quality emerged as indirect factor to influence customers' attitude to adopt internet banking. The indirect effect through perceived ease of use and perceived usefulness have a significant influence on attitude towards adopting internet banking service. The results of this study indicate that when customer perceives that internet banking service is efficient, the website is available for transactions, customers are confident and their tasks are completed provided the required assistance from employees, data submitted on website are safe and private and customers find the website to be attractive they will feel that internet banking is more useful and easy to use. In this study, electronic service quality is found to have a strong effect on perceived ease of use and perceived usefulness as confirmed with the results of the previous studies (Chandio, 2011).

Third finding reveals that other constructs of model (PU, PEOU and attitude) have a significant influence on intention to adopt. Attitude has emerged as a mediator between constructs of PU, PEOU and intention. This is similar to the finding of Lee (2009, p. 137) who indicated PU, PEOU and attitude affect the behavioral intention. However, 
perceived ease of use does not affect perceived usefulness in this context against the study of Eze et al. (2011, p. 520). Since internet banking provides convenience and saves time irrespective of bank chosen, it might not be the important factor contributing to the perceived usefulness. Another finding shows the significant relationship between attitude and behavioral intention (Shima \& Mohamadali, 2017, p. 836). Thus, the results supported most of the developed hypotheses relationships, except for the TAM basic postulation, perceived ease of use could not found to be significant and positively related to perceived usefulness.

The growing population in line with shifting cultures and demographics fuels a rivalry among enterprises and also leads firms to work on their service delivery quotient. Customers hesitate to use electronic banking because of perceived risk and this makes banks focus on building customer trust and satisfaction by providing service quality. This will lead banks to improve upon user interface that can fulfil customers' requirements efficiently and make their transactions completed securely. Thus, in an online service context, customer will do transactions based on the customer experience with the bank (Davis, 2007, p. 7). As expected, the results of this study confirms the cognitive-affective-conative behavior model for the determinants of electronic service quality, perceived ease of use and perceived usefulness, as well as electronic service quality, customer attitude, and intention to adopt internet banking.

\section{MANAGERIAL IMPLICATIONS}

The results are consistent with many other authors having opinion that the older generation have to put quite a high level of emotional effort to learn new behaviors as supported by Katz and Aspden (1997, p. 174) findings that the younger segment mostly are the users of internet banking. Also, the proven hypothesis that electronic service quality exerts significant influence on intention to adopt internet banking provides meaningful implications for banks, as they would have to allocate their resources accordingly to encourage promoting service quality for their internet banking service. Customers place importance to visual layout and up-to-date information provided by website. Thus, banks need to focus on providing good websites with security measures at place and technical feasibilities. They also need to educate customers about such security measures and policies of internet banking operations (Singh, 2019). This study also suggests that banks should consider focusing on functionalities and speed of the e-banking website. As results show, customers' beliefs about its convenience do not really encourage their perception towards its usefulness, since today's customers are tech savvy and have up-to-date computer knowledge and use it for many purposes. Speed and convenience of e-banking is minimum thing that would influence their attitude, it's the relative advantage, features, functionalities, offers and other benefits that would attract young generation towards internet banking. Since electronic service quality is developed with a scale having so many components and its important antecedents, it is important to understand what components are important for each type of customers and if antecedents can be added in terms of preferential treatment, service recovery and trust in the brand. The essence of service quality is that it should be experienced and sometimes transmitted and thus the focus should be on communicating the quality of e-banking system created by banks to its customers to let them try their new offerings. The ultimate inference is for customer to start using internet banking, he/she should be able to find it friendly and beneficial, such that they value it over traditional banking, and for customers to continue using internet banking, the electronic service quality should be good, such that it can enhance responsiveness, provide assurance and privacy to customers. Bank managers should exert their effort in redirecting their strategies towards confirming that the above conditions are established to convert more offline customers into online customers.

\section{CONCLUSION AND FUTURE SCOPE}

In addition to implications for management, this research provides practical aspects too. This paper has developed extended TAM integrating e-service quality to predict and explain customers' intention to 
adopt internet banking. The structural equation modelling confirms the model good fitness in explaining the behavioral intention of young customers to adopt internet banking. This research had some limitations with respect to geographical area and was based on cross-sectional data, thus, generalization of findings should be considered carefully. Moreover, technology has been dynamic and changing rapidly. The factors that influence adoption today might not influence tomorrow. So, there is always a scope to identify the new functionalities into the system and understand what part of customer's mental, social or physical stimuli influences it. The primary goal of providing internet banking by banks is to increase efficiency and profitability by reducing costs, therefore, a study from management of the bank is also important to understand customer's approach as how they leverage on technology and try to gain competitive advantage. Understanding right strategy mechanism can also drive customer's behavior towards internet banking more positively.

\section{REFERENCES}

1. Aboelmaged, M., \& Gebba, T. R. (2013). Mobile banking adoption: an examination of technology acceptance model and theory of planned behavior. International Journal of Business Research and Development, 2(1). http://dx.doi. org/10.24102/ijbrd.v2i1.263

2. Agarwal, R., \& Karahanna, E. (2000). Time flies when you're having fun: Cognitive absorption and beliefs about information technology usage. MIS quarterly, 24(4), 665-694. https://doi. org/10.2307/3250951

3. Ajzen, I. (1985). From intentions to actions: A theory of planned behavior. In Action control (pp. 11-39). Springer, Berlin, Heidelberg. Retrieved from https://link.springer.com/chapter/10.1007/978-3-642-69746-3_2

4. Ajzen, I. (2002). Constructing a TPB questionnaire: Conceptual and methodological considerations. Retrieved from https:// www.semanticscholar.org/ paper/Constructing-a-TpBQuestionnaire\%3A-Conceptualand-Ajzen/0574b20bd58130dd5a9 61f1a2db10fd1fcbae95d

5. Ajzen, I., \& Fishbein, M. (1975). Belief, attitude, intention and behavior: An introduction to theory and research. Retrieved from https://www.researchgate.net/ publication/233897090_Belief_attitude_intention_and_behaviour_An_introduction_to_theory_ and_research

6. Alsajjan, B., \& Dennis, C. (2010). Internet banking acceptance model: Cross-market examination. Journal of Business Research, 63(9), 957-963. https://doi.org/10.1016/j. jbusres.2008.12.014

7. Al-Somali, S. A., Gholami, R., \& Clegg, B. (2008, September). Internet banking acceptance in the context of developing countries: An extension of the Technology Acceptance Model. Paper presented at European Conference on Management of Technology. Retrieved from https://www.researchgate.net/ publication/228470235_Internet_Banking_Acceptance_in_the Context_of_Developing_Countries_An_Extension_of_the_Technology_Acceptance_Model

8. Amin, M. (2016). Internet banking service quality and its implication on e-customer satisfaction and e-customer loyalty. International Journal of Bank Marketing, 34(3), 280-306. https://doi.org/10.1108/ IJBM-10-2014-0139

9. Ariff, M. S. M., Yun, L. O., Zakuan, N., \& Jusoh, A. (2012). Examining dimensions of electronic service quality for internet banking services. Procedia-Social and Behavioral Sciences, 65, 854-859. https://doi.org/10.1016/j.sbspro.2012.11.210

10. Bandura, A. (1986). The explanatory and predictive scope of self-efficacy theory. Journal of social and clinical psychology, 4(3), 359-373. https://doi.org/10.1521/ jscp.1986.4.3.359

11. Bashir, I., \& Madhavaiah, C. (2014). Determinants of young consumers' intention to use Internet banking services in India. Vision, 18(3), 153-163. https://doi.org/10.1177\%2F0972262914538369

12. Bashir, I., \& Madhavaiah, C. (2015). Consumer attitude and behavioural intention towards Internet banking adoption in India. Journal of Indian Business Research, 7(1), 67-102. https://doi. org/10.1108/JIBR-02-2014-0013

13. Bauer, H. H., Hammerschmidt, M., \& Falk, T. (2005). Measuring the quality of e-banking portals. International journal of bank marketing, 23(2), 153-175. https://doi. org/10.1108/02652320510584395

14. Bitner, M. J., \& Hubbert, A. R. (1994). Encounter satisfaction versus overall satisfaction versus quality. Service quality: New directions in theory and practice, 34(2), 72-94. http://dx.doi. org/10.4135/9781452229102.n3

15. Boakye, K. G., McGinnis, T., \& Prybutok, V. R. (2014). Q-TAM: a quality technology acceptance model for technology operations managers. Operations Management Research, 7(1-2), 13-23. https://doi.org/10.1007/ s12063-014-0085-x

16. Bruner, G. C., \& Kumar, A. (2005). Explaining consumer acceptance of handheld Internet devices. Journal of business research, 58(5), 553-558. https://doi.org/10.1016/j. jbusres.2003.08.002

17. Chandio, F. H. (2011). Studying acceptance of online banking 
information system: A structural equation model (Doctoral dissertation, Brunel University Brunel Business School Ph.D. Theses). Retrieved from https:// www.researchgate.net/publication/277827264_Studying_acceptance_of_online_banking_information_system_A_structural_ equation_model

18. Clonia, R., \& Asht, M. (2016). E-banking in India: Current and future prospects. IJABER, 14(7), 5369-5381. Retrieved from https://www.researchgate. net/publication/308222670_Ebanking_in_India_Current_and_ future_prospects

19. Davis, F. D. (1989). Perceived usefulness, perceived ease of use, and user acceptance of information technology. MIS quarterly, 13(3), 319-340. https:// doi.org/10.2307/249008

20. Davis, F. D., Bagozzi, R. P., \& Warshaw, P. R. (1992). Extrinsic and intrinsic motivation to use computers in the workplace. Journal of applied social psychology, 22(14), 1111-1132. https://doi. org/10.1111/j.1559-1816.1992. tb00945.x

21. De Ruyter, K., Wetzels, M., \& Kleijnen, M. (2001). Customer adoption of e-service: an experimental study. International journal of service industry management, 12(2), 184-207. https://doi.org /10.1108/09564230110387542

22. Eriksson, K., Kerem, K., \& Nilsson, D. (2005). Customer acceptance of internet banking in Estonia. International journal of bank marketing, 23(2), 200-216. https://doi. org/10.1108/02652320510584412

23. Eze, U. C., Goh, M. H., Ling, H. Y., \& Lee, C. H. (2011, November). Intention to use e-government services in Malaysia: Perspective of individual users. In International Conference on Informatics Engineering and Information Science (pp. 512-526). Berlin: Heidelberg. Retrieved from https://link.springer.com/chapter/10.1007/978-3-642-25453-6_43

24. Firdous, S., \& Farooqi, R. (2017). Impact of internet banking service quality on customer satisfaction. The Journal of Internet Banking and Commerce, 22(1), 1-17.

Retrieved from http://www.icommercecentral.com/open-access/ impact-of-internet-banking-service-quality-on-customer-satisfaction.php?aid $=85570$

25. Fornell, C., \& Larcker, D. F. (1981) Structural equation models with unobservable variables and measurement error: Algebra and statistics. Journal of marketing research, 18(3), 382-388. https:// doi.org/10.2307/3150980

26. George, A., \& Kumar, G. G. (2014). Impact of service quality dimensions in internet banking on customer satisfaction. Decision, 41(1), 73-85. http://dx.doi. org/10.1007/s40622-014-0028-2

27. Gupta, K. K., \& Bansal, I. (2012). Development of an instrument to measure internet banking service quality in India. Researchers World, 3(2 Part 2), 11-25. Retrieved from https://pdfs.semanticscholar.org/2 6ba/6b23513272d29c48bbb928ad7 5ad4d6a73f5.pdf

28. Hammoud, J., Bizri, R. M., \& El Baba, I. (2018). The Impact of E-Banking Service Quality on Customer Satisfaction: Evidence from the Lebanese Banking Sector. SAGE Open, 8(3). https://doi.org/10.1177\%2F2158244018790633

29. Hien, N. M. (2014). A study on evaluation of e-government service quality. International Journal of Social, Management, Economics and Business Engineering, 8(1), 16-19. Retrieved from https://www.semanticscholar. org/paper/A-Study-on-Evaluation-of-E-Government-ServiceHien/baca7b32c74737f7e2791f4c9a71e63d3a3e1694

30. Ho, C. T. B., \& Lin, W. C. (2010). Measuring the service quality of internet banking: scale development and validation. European Business Review, 22(1), 5-24. https://doi. org/10.1108/09555341011008981

31. Hosein, N. Z. (2009). Internet Banking: An Empirical Study of Adoption Rates among Midwest Community Banks. Journal of Business Economics \&
Research, 7(11), 51-72. https://doi. org/10.19030/jber.v7i11.2355

32. Jayawardhena, C., \& Foley, P. (2000). Changes in the banking sector - the case of Internet banking in the UK. Internet Research, 10(1), 19-31. https://doi. org/10.1108/10662240010312048

33. Jung, N. Y., \& Seock, Y. K. (2016). The impact of corporate reputation on brand attitude and purchase intention. Fashion and Textiles, 3(1), 20. Retrieved from https://link.springer.com/article/10.1186/s40691-016-0072-y

34. Kadir, H. A., Rahmani, N., \& Masinaei, R. (2011). Impacts of service quality on customer satisfaction: Study of Online banking and ATM services in Malaysia. International Journal of Trade, Economics and Finance, 2(1), 1. http://dx.doi.org/10.7763/ IJTEF.2011.V2.71

35. Karjaluoto, H., Mattila, M., \& Pento, T. (2002). Factors underlying attitude formation towards online banking in Finland. International journal of bank marketing, 20(6), 261-272. https://doi. org/10.1108/02652320210446724

36. Katz, J., \& Aspden, P. (1997). Motivations for and barriers to internet usage: results of a national public opinion survey. Internet Research: Electronic Networking Application and Policy, 7(3), 170-188. https://doi. org/10.1108/10662249710171814

37. Khan, M. S., \& Mahapatra, S. S. (2009). Service quality evaluation in internet banking: an empirical study in India. International Journal of Indian Culture and Business Management, 2(1). http://dx.doi.org/10.1504/IJICBM.2009.021596

38. Khanifar, H., Nia, M., Javad, M., Molavi, Z., \& Emami, M. (2012). Factors influencing the intendancy of e-banking: An integration of TAM \& TPB with e-service quality. Journal of Applied Sciences Research, 8(3), 1842-1852. Retrieved from https:// www.researchgate.net/publication/260598018_Factors_influencing_the_intendancy_of_E-Banking_An_integration_of_TAM_ TPB_with_e-service_quality 
39. Laforet, S., \& Li, X. (2005). Consumers' attitudes towards online and mobile banking in China. International journal of bank marketing, 23(5), 362-380. https://doi. org/10.1108/02652320510629250

40. Lai, P. C. (2017). The literature review of technology adoption models and theories for the novelty technology. JISTEMJournal of Information Systems and Technology Management, 14(1), 21-38. https://doi/org/10.4301/ s1807-17752017000100002

41. Lai, V. S., \& Li, H. (2005). Technology acceptance model for internet banking: an invariance analysis. Information \& management, 42(2), 373386. https://doi.org/10.1016/j. im.2004.01.007

42. Lee, M. C. (2009). Factors influencing the adoption of internet banking: An integration of TAM and TPB with perceived risk and perceived benefit. Electronic commerce research and applications, 8(3), 130-141. https://doi.org/10.1016/j.elerap.2008.11.006

43. Liao, Z., \& Cheung, M. T. (2002). Internet-based e-banking and consumer attitudes: an empirical study. Information \& Management, 39(4), 283-295. https://doi.org/10.1016/S03787206(01)00097-0

44. Maduku, D. K. (2013). Predicting retail banking customers' attitude towards Internet banking services in South Africa. Southern African Business Review, 17(3), 76-100. Retrieved from htps://www.ajol. info/index.php/sabr/article/ view/110928

45. Mohd-Any, A. A., Mahdzan, N. S., \& Valinejad, H. (2016). Young adults' perceptions of online service quality. International Journal of Electronic Marketing and Retailing, 7(2), 91-114. https://doi.org/10.1504/ IJEMR.2016.077115

46. Mundra, S. S. (2015). Financing India's growth-challenges and way ahead. Retrieved from https:// www.bis.org/review/r150921a.htm

47. NezamZade, Farzin (2009). The study of factors influencing the electronic environment of banking service delivery and its influence on customer behavior (Case study: branches of SepahBankin Tehran) (Master Thesis of Administration Management, Faculty of Management, Qom Campus, University of Tehran).

48. Nupur, J. M. (2010). E-banking and customers' satisfaction in Bangladesh: An analysis. International review of business research papers, 6(4), 145-156. Retrieved from http://unpan1. un.org/intradoc/groups/public/ documents/apcity/unpan046044. pdf

49. Parasuraman, A., Zeithaml, V. A., \& Berry, L. L. (1985). A conceptual model of service quality and its implications for future research. The Journal of Marketing, 41-50. https://doi.org/10.2307/1251430

50. Parasuraman, A., Zeithaml, V. A., \& Berry, L. L. (1988). Servqual: A multiple-item scale for measuring consumer perc. Journal of retailing, 64(1), 12. Retrieved from https://search.proquest. com/openview/7d007e04d78261 295e5524f15bef6837/1?pq-origsite $=$ gscholar $\& \mathrm{cbl}=41988$

51. Parasuraman, A., Zeithaml, V. A., \& Malhotra, A. (2005). ESQUAL: A multiple-item scale for assessing electronic service quality. Journal of service research, 7(3), 213-233. Retrieved from https://www.researchgate.net/publication/258158801_E-S-Qual_A Multiple-Item_Scale_for_Assessing_Electronic_Service_Quality

52. Ranganathan, C., \& Ganapathy, S. (2002). Key dimensions of business-to-consumer web sites. Information \& Management, 39(6), 457-465. https://doi.org/10.1016/ S0378-7206(01)00112-4

53. Rogers, E. M. (2003). Diffusion of innovations (5th ed.). New York: Free Press.

54. Safeena, R., Date, H., Hundewale, N., \& Kammani, A. (2013). Combination of TAM and TPB in Internet banking adoption. International Journal of Computer Theory and Engineering, 5(1), 146. https://doi.org/10.7763/ IJCTE.2013.V5.665

55. Sebetci, Ö. (2015). A TAM-based model for e-government: a case for Turkey. International Journal of Electronic Governance, 7(2), 113-135. Retrieved from https:// www.academia.edu/33206751/A TAM_based_Model_for_Egovernment_A_Case_for_Turkey

56. Shen, C. C., \& Chiou, J. S. (2009). The effect of community identification on attitude and intention toward a blogging community. Internet Research, 19(4), 393-407. https://doi. org/10.1108/10662240910981362

57. Shima, N., \& Mohamadali, A. K. (2017). Examining the factors affecting willingness to use electronic banking: the integration of TAM and TPB models with electronic service quality (case study: EghtesadNovin Bank). Journal of Fundamental and Applied Sciences, 9(1S), 824-841. Retrieved from https://www. ajol.info/index.php/jfas/article/ view/159186/157627

58. Shin, D. H. (2009). Determinants of customer acceptance of multiservice network: An implication for IP-based technologies. Information \& Management, 46(1), 16-22. https://doi.org/10.1016/j. im.2008.05.004

59. Singh, S. (2019). Measuring E-Service Quality and Customer Satisfaction with Internet Banking in India. Theoretical Economics Letters, 9(2), 308-326. https://doi. org/10.4236/tel.2019.92023

60. Sohail, M. S., \& Shaikh, N. (2008). Internet banking and quality of service Perspectives from a developing nation in the Middle East. Online Information Review, 32(1), 58-72. https://doi.org/10. 1108/14684520810865985

61. Suh, B., \& Han, I. (2002). Effect of trust on customer acceptance of Internet banking. Electronic Commerce Research and Applications, 1(3\&4), 247-263. 
https://doi.org/10.1016/S15674223(02)00017-0

62. Sum Chau, V., \& Ngai, L. W. (2010). The youth market for internet banking services: perceptions, attitude and behaviour. Journal of Services Marketing, 24(1), 42-60. https://doi.org/10.1108/08876041011017880

63. Taherdoost, H. (2018). Development of an adoption model to assess user acceptance of e-service technology: E-Service Technology Acceptance Model. Behaviour \& Information Technology, 37(2), 173-197. https://doi.org/10.1080/014492 9X.2018.1427793

64. Tardivo, G., Viassone, M., \& Gola G. L. (2014). Young Customers' Perception of the Quality of M-banking Services. Universal
Journal of Industrial and Business Management, 2(8), 200-209. https://doi.org/10.13189/ ujibm.2014.020802

65. Taylor, S., \& Todd, P. A. (1995). Understanding information technology usage: A test of competing models. Information systems research, 6(2), 144-176. Retrieved from https://www.jstor. org/stable $/ 23011007$ ? seq=1\#page scan_tab_contents

66. Venkatesh, V., \& Davis, F. D. (2000). A theoretical extension of the technology acceptance model: Four longitudinal field studies. Management science, 46(2), 186204. https://doi.org/10.1287/ mnsc.46.2.186.11926

67. Venkatesh, V., Morris, M. G., Davis, G. B., \& Davis, F. D. (2003). User acceptance of information technology: Toward a unified view. MIS quarterly, 425-478. https://doi. org/10.2307/30036540

68. Yoo, B., \& Donthu, N. (2001). Developing and validating a multidimensional consumerbased brand equity scale. Journal of business research, 52(1), 1-14. https://doi.org/10.1016/S01482963(99)00098-3

69. You, C. S, Grant, K., \& Adgar, D. (2007). Factors affecting the adoption of Internet Banking in Hong kong-implication for the banking sector. International Journal of Information management, 27(5), 336-351. https://doi.org/10.1016/j.ijinfomgt.2007.03.002

70. Yousafzai, F., \& Pallister (2007). Technology acceptance: a Meta analysis of the TAM. Journal of Modeling in Management, 2(3), 251-280. https://doi. org/10.1108/17465660710834453 